\title{
女子学生に関する12分間走テストの低位者と高位者の 体組成・有酸素および無酸素的能力の検討
}

\author{
平川和文 (神戸大学・教養部) \\ 植野早苗 (大阪府立天王寺高等学校) \\ 家 治川豊 (神戸大学・教養部) \\ （昭和58年10月19日受付）
}

Study of body composition and aerobic and anaerobic abilities between low and high performance groups of female studients in 12-min run

\author{
Kazufumi Hirakawa' \\ Sanae Ueno ${ }^{2}$ \\ Yutaka Kajikawa!
}

\begin{abstract}
The purpose of this study was to compare the body compostition and aerobic and anaerobic abilities between low and high performance groups of female students in 12-min run. Hight, weight, $\%$ body fat, vertical jump, and 12 -min run performance were measured on 437 female students. Their mean $( \pm \mathrm{SD}$ ) value of 12 -min run performance was $2208.5 \pm 165.7 \mathrm{~m}$. Out of 437 girls tested, 9 girls (group L) whose 12-min run performace were lower than $1959 \mathrm{~m}$, and 14 girls (group $\mathrm{H}$ ) whose performance were higher than $2457 \mathrm{~m}$ volunteered as the subjects. The leg volume, Voz $\max$, anaerobic threshold (AT), $\dot{\mathrm{V}}_{2}$ at submaximal treadmill running, maximal leg strength, and maximal anaerobic power were measured. Group $\mathrm{L}$ differed significantly $(\mathrm{p}<0.001)$ from group $\mathrm{H}$ in $\dot{V}_{\mathrm{z}} \max$ $(38.5 \pm 2.2$ vs $47.1 \pm 3.1 \mathrm{ml})$. $\dot{\mathrm{V}}_{2} \max$ per $\mathrm{LBM}$ of group $\mathrm{L}$ was also lower $(15.9 \%)$ than that of group $\mathrm{H}$, but muscle and bone volume of leg was similar in both groups. Group $\mathrm{L}$ tended to show the larger values in weight $(4.6 \%), \%$ body fat $(10.0 \%)$, and $\dot{V}_{o_{2}}$ at $130 \mathrm{~m} / \mathrm{min}$ (running economy) $(5.4 \%$ ) as compared with group $H$. There were no differences in AT, HR max, and maximal leg strength between the two groups. AT values of both groups appeared at about $62 \%$ of $\mathrm{Vo}_{2}$ max. Maximal anaerobic power per body weight of group L was lower $(11.4 \%, \mathrm{p}<0.01)$ than that of group $\mathrm{H}$, which was caused by the slow velocity of group $\mathrm{L}$ at the maximal anaerobic power on the force-velocity relationship. On results of multiple-regression analysis predicting the 12 -min run performance from
\end{abstract}

1 Kobe University, College of Liberal Arts, Department of Physical Education, Tsurukabuto, Nada-ku, Kob, Hyogo (657)

2 Tennooji High School, sanmei-cho, Abeno-ku, Osaka (545) 
other variables in the combined group, the relative importance of the independent variables as determinants of 12 -min run performance were in order of $\dot{V}_{o_{2}} \max (\mathrm{ml} / \mathrm{kg} / \mathrm{min})$, running economy, and maximal anaerobic power per body weight. This multiple-regression equation accounted for $93.6 \%$ of the variance of 12-min run performance.

(Kazufumi Hirakawa, Sanae Ueno and Yutaka Kajikawa, "Study of body composition and aerobic and anaerobic abilities between low and high performance groups of female students in 12-min run", Jap. J. Phys. Educ., 29-3 : 237-44, December, 1984)

\section{精}

䤅

高度に持久性トレーニングを積んだ者は，最大

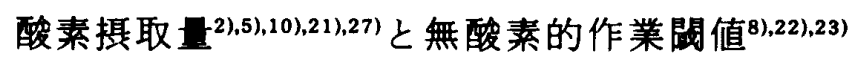
（以後 AT と示す.）が大きく，同一最大下作業時

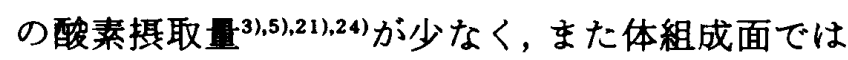

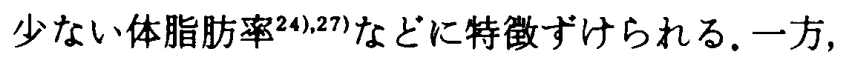
無酸素的能力の面では，一般に有酸素的能力との 間には負の相関関係にあるとされているよう $に^{60,13), 15)}$, 有酸素的能力に優れた者は最大無酸素 パワーおよびキャパシティーが，スプリント的ト レーニングを積んだ者より劣るとされている。こ のよ5に，個人が同時に有酸素および無酸素的能 力の双方に優れた能力を持つことはきわめて希で あり，そのいずれかに特徽が示される1)。しかし， トレーニングされていない一般人については，測 定によってどの程度個人の能力的特徵が示される ものかは十分研究されていないよらに思われる。

有酸素的持久能のフィールド・テストとしては, 最大酸素摃取量との相関が高い 5 分間走あるいは 12分間走テストが採用され，一般人の測定に広く 利用されている25).しかし，このフィールド・テス トでは，個人の身体資源の特徵がどの程度評価さ れるのかといら疑問がある。また，特に持久力の 㸓る女子学生について，体組成・有酸素的および 無酸秦的能力の特徵を総合的に評価している報 告3),14),17) は少ないよ5に思われる。

そこで, 本研究では一般女子学生を対象として, 12分間テストの大きく劣る者と逆に優れた者につ いて，体組成・有酸素的能力・無酸素パワー・脚 筋力の面から比較検討して, 持久力低位者の特徵 を探り，合わせて12分間走距離に対する各測定項 目の影響を検討しょうとするものである。

\section{实 张 方 法}

\section{1. 被匼者}

昭和 57 年度神戸大学女子新入生 437 名に対して, 12分間走テスト・垂直とび・身長・体重・皮下脂 肪厚（上腕背部と眉甲骨下部の 2 点）からの体脂 肪率 ${ }^{19}$ の測定を行った．12分間走テストの走行距 離はFig. 1のような分布を示し，平均値と標準偏 差は2,208.5土165.7m であった，正規性の検定の 結果は急尖の傾向が見られ，平均値の近くに多く 集まっていた。この12分間走距離について，平均 值を中心に 1 標準偏差ごとの幅で 5 段階に区分 (Fig. 1の下段)し, 走行距離が1,959m 以下の最も 贫るグループ (Fig. 1の左下りの斜線部分に属す る35名）と，2,457m 以上の最も優れたグループ （Fig. 1の右下りの斜線部分に属する23名）との, 2 つの有酸素的作業能の劣るクループと優れたク ループを選んだ.さらにこの 2 グループの中から， 両グループとも現役入学生を対象とし, 最も劣る グループについては中学・高校・大学と運動部経 験のない者 9 名（以後，低位者群と示す.）を, 一 方，最も優れたグループについては中学・高校で の運動部経験の有無には制限をつけなかったが, 大学では規則的なトレーニングを行っていない者 14名(以後, 高位者群と示す.)の計23名に対して, 下記の各測定を行った。

\section{2. 測定项目および方法}

形態・体組成の測定は，身長・体重・体脂肪率 の他に, Jones ${ }^{12)}$ の方法に従い右下肢の諸計測値よ り, 脚容量・脚の骨および筋容量(除脂肪脚容量) ・ 脚脂肪量を求めた。なお本研究においては，右大 腿部と下腿部の合計值でもって各脚容量とした。 最大酸素摂取量と走効率 (running economy) 

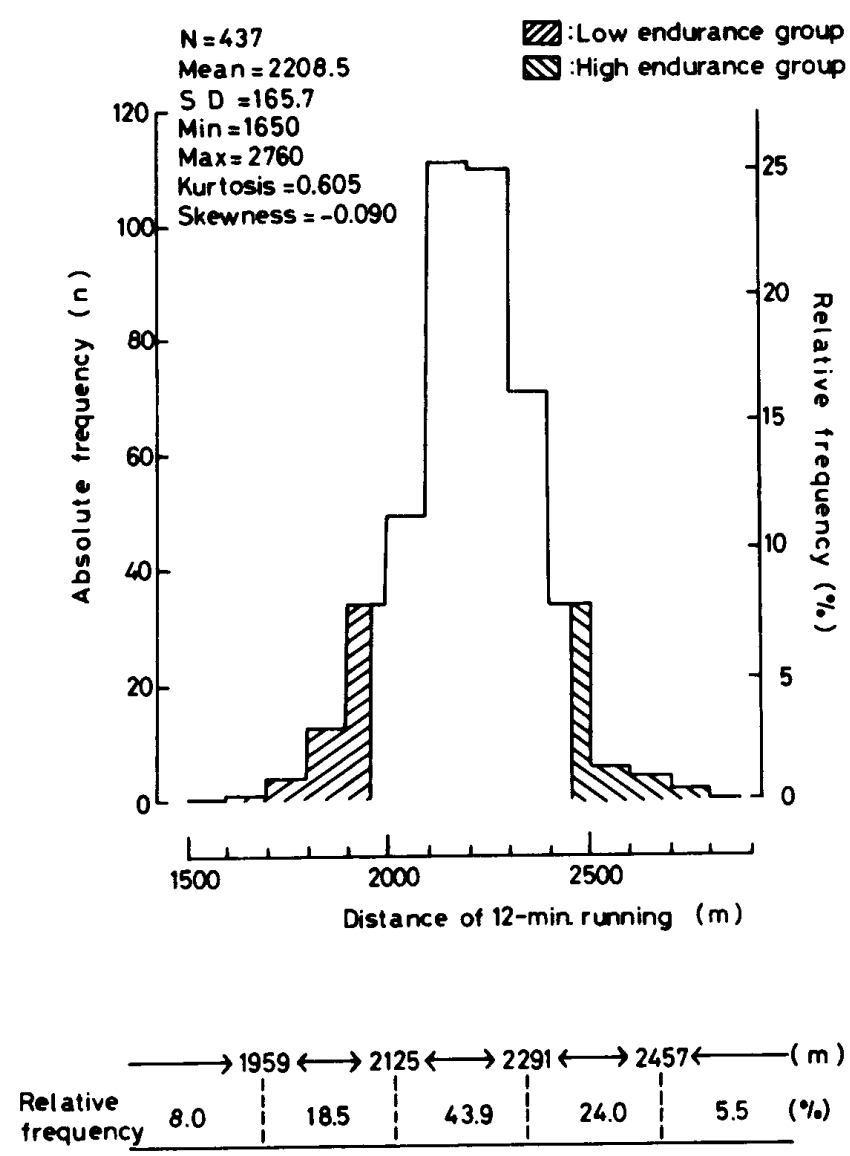

Fig. 1 Histogram of 12-min run performance of 437 female students.

の測定は, 斜度 0 度で $3-4$ 種類の 4 分每の最大 下スピードの後, exhaustion 迄 1 分毎にスピード を $10 \mathrm{~m}$ 漸増するトレッドミル速度漸増法により 行った。最大下の各走行スピードは，低位者群で は $100,120 \mathrm{~m} / \mathrm{min}$ 扎よび各被験者の 12 分間走の平 均走行スピード $(142-160 \mathrm{~m} / \mathrm{min})$ の 3 種類であ ク，高位者群では $100,120,160 \mathrm{~m} / \mathrm{min}$ および12分 間走の平均走行スピード $(205-228 \mathrm{~m} / \mathrm{min})$ の 4 種類とした。呼気ガスの採気は各スピードの最後 の 1 分間にダグラス・バッグ法により行い, $\mathrm{O}_{2}$, $\mathrm{CO}_{2}$ の分析には瞬時呼気ガス分析装置 (三栄測器 社製）を用い，湿式ガスメーターによる呼気量の 計測值とから酸素摄取量を求めた。なお，較正は 労研式ガス分析装置により行った。測定中は胸部 双極誘導による心電図とサーミスター法による呼 吸曲線を連続記録し，心拍数と呼吸数を合わせて 測定した。 また，各走行スピード時の終了30秒前

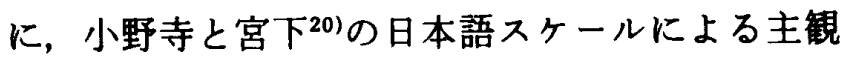
的運動強度 (以後, RPE と示寸.) を測定し，最終
走行スピード時の RPEでもって12分間走テスト の“努力感”の指標とした。最大酸素摂取量出現 の判定基準は，心拍数が 180 拍/分以上または $R Q$ が1.0以上であることより決定した。最大酸素摂取 量出現時の心拍数と $\mathrm{RQ}$ の平均值と標準偏差は, それぞれ187.4土10.6拍/分, 1.08土0.07であった。 各被験者の走行スピードと酸素摄取量 $(\mathrm{ml} / \mathrm{kg}$ ・ min）の関係から回㷌直線を求め（相関係数は $0.985 \pm 0.026)$, 走行スピード $130 \mathrm{~m} / \mathrm{min}$ 時の酸素 摂取量を計算し，走奻率 (running economy) の

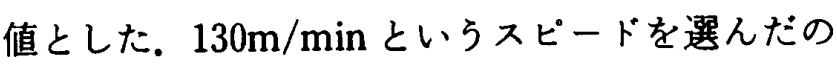
は，低位者群の12分間走の平均スピードが $142-160 \mathrm{~m} / \mathrm{min}$ の範囲であったため, $142 \mathrm{~m} / \mathrm{min}$ 以下のスピードといらことで選んだ.

ATの測定はモナーク社製自転車エルゴメー ターを用い，回転数を $44 \mathrm{rpm} に$ 規定して荷重を 1 分間に0.5kpずつ漸増することにより疲労困㑑ま で追い込み，酸素摄取量・炭酸ガス産生量・換気 昔を連続測定した。ATの決定は Davies らのの方 法に従い，換気量・炭酸ガス産生量の非直線的増 加点でもって決定し，その時点の\% $\dot{\mathrm{VO}}_{2} \max て ゙$ もって示した。

最大無酸素パワーの測定には自転車エルゴメー ターを用い, 生田ら ${ }^{11}$ の方法に従って荷重0一7kp での最大べタリングを各10秒間行わせ, その力 一速度関係を 2 次曲線でフィッティングし，その ピーク值でもって最大無酸素パワーを決定した。 また，サイベックスIIにより，㮏角度 $60 ， 90,120$ 度時のアイソメトリック膝伸展筋力を測定し, そ れらの最大值でもって最大脚伸展筋力とした。

以上の測定は, 昭和57年 9 月から11月に実施し た。な拉，各被験者ともすべてその測定は 2 週間 以内に行い, 自転車エルゴメーターとトレッドミ ルによる測定の間には, 少なくとも1日の休息を はさんだ。

すべての平均値の有意差検定はStudent の対 応のないt-testにより行い，5\%水準以上でもっ て有意とした。ま，重回㷌分析はSPSS 統計 パッケージの new regression (step wise 方式) を使用した。 
Table 1. Summary of the physical and performance measures in all female students and low and high endurance groups.

\begin{tabular}{|c|c|c|c|c|c|}
\hline \multirow{2}{*}{ Variable } & All students $\dagger$ & LEG †† & HEG $+\dagger+$ & \multirow{2}{*}{$\begin{array}{l}\text { Mean } \\
\text { difference }\end{array}$} & \multirow{2}{*}{$\mathbf{R}$} \\
\hline & Mean \pm SD & Mean $\pm S D$ & Mean \pm SD & & \\
\hline $\mathrm{N}$ of subjects & 437 & 35 & 23 & & \\
\hline Height $(\mathrm{cm})$ & $158.2 \pm 4.7$ & $158.3 \pm 4.0$ & $155.8 \pm 4.4$ & $2.5^{*}$ & -0.039 \\
\hline Weight $(\mathbf{k g})$ & $51.1 \pm 5.5$ & $54.0 \pm 7.8$ & $48.5 \pm 5.1$ & $5.5^{* *}$ & $-0.158^{* * *}$ \\
\hline $12 \cdot \min \operatorname{run}(\mathrm{m})$ & $2208.5 \pm 165.8$ & $1882.9 \pm 73.8$ & $2574.0 \pm 88.6$ & $-691.1^{* * *}$ & \\
\hline Vertical jump $(\mathrm{cm})$ & $42.2 \pm 5.9$ & $38.5 \pm 5.4$ & $45.2 \pm 7.0$ & $-6.7 * *$ & $0.281 * *$ \\
\hline$\%$ Body fat $(\%)$ & $21.5 \pm 3.4$ & $23.1 \pm 3.9$ & $20.3 \pm 3.5$ & $2.8^{* *}$ & $-0.169 * \ldots$ \\
\hline Rohrer index & $129.3 \pm 13.2$ & $136.4 \pm 20.6$ & $128.4 \pm 13.0$ & 8.0 & $-0.143^{* *}$ \\
\hline \multirow{2}{*}{\multicolumn{6}{|c|}{$\begin{array}{l}\uparrow: 437 \text { female students who were performed } 12 \text {-min run test. } \\
\text { t† : Low endurance group whose } 12 \text {-min run performance was lower than } 1959 \mathrm{~m}\end{array}$}} \\
\hline & & & & & $\begin{array}{l}\text { It : Low endurance group whose } 12 \text {-min run performance was lower than } 1959 \mathrm{~m} \text {. } \\
\text { ttt : High endurance group whose } 12 \text {-min run performance was higher than } 2457 \mathrm{~m}\end{array}$ \\
\hline \multicolumn{6}{|c|}{$\begin{array}{l}\text { Mean difference : Mean difference value between } \mathrm{LEG} \text { and HEG. } \\
\mathrm{R}: \text { Correlation coefficient between } 12 \text {-min }\end{array}$} \\
\hline $\mathrm{R}$ : Correlation coe & nt between $12-\mathrm{m}$ & n run perform & ace and each va & & \\
\hline
\end{tabular}

\section{結果}

Table 1 は，女子新入生全員 (437名) ならびに 12分間走テストの 5 段階区分による最も劣るグ ループ（表中の LEG）と優れたグループ（表中の $\mathrm{HEG)}$ について, 各項目の平均値と標準偏差, 12 分間走之の相関係数，ならびに両グループ間の各 項目の平均値の差とその有意性を示している，女 子新入生全員の身長・体重・垂直とび・体脂肪率 は，同年齢の日本人女子の值と同様な値であっ た ${ }^{16), 26)}$. 12分間走距離の平均値は, 体育科学セン ター ${ }^{25)}$ の同年齢の值より約 $60 \mathrm{~m}$ 優れていた。 12 分 間走距離の最も劣るグループと優れたグループを 比較すると，劣るグループは優れたグループより 体重は5.5kg(11.3\%)，体脂肪率は $2.8 \%(13.7 \%)$ と $1 \%$ 水準で有意に大きく，逆に垂直とびは 6.7 $\mathrm{cm}(14.8 \%)$ と0.1\%水準で有意に劣っていた. 12 分間走距離は体重・体脂肪率とは負の相関関俰が, 垂直とびは正の関係が見られた。

表 2 は低位者群 9 名（図表中の group L）と高 位者群14名（図表中の group H）について，各測 定項目の平均値と標準偏差拈よび両群の平均値の 差とその有意性を示している，またFig. 2はそれ ぞれの測定項目について，高位者群の值を基準之 した低位者群の值の増減率（\%）を示している。 両群を比較すると, 体重・体脂肪率・脚容量など

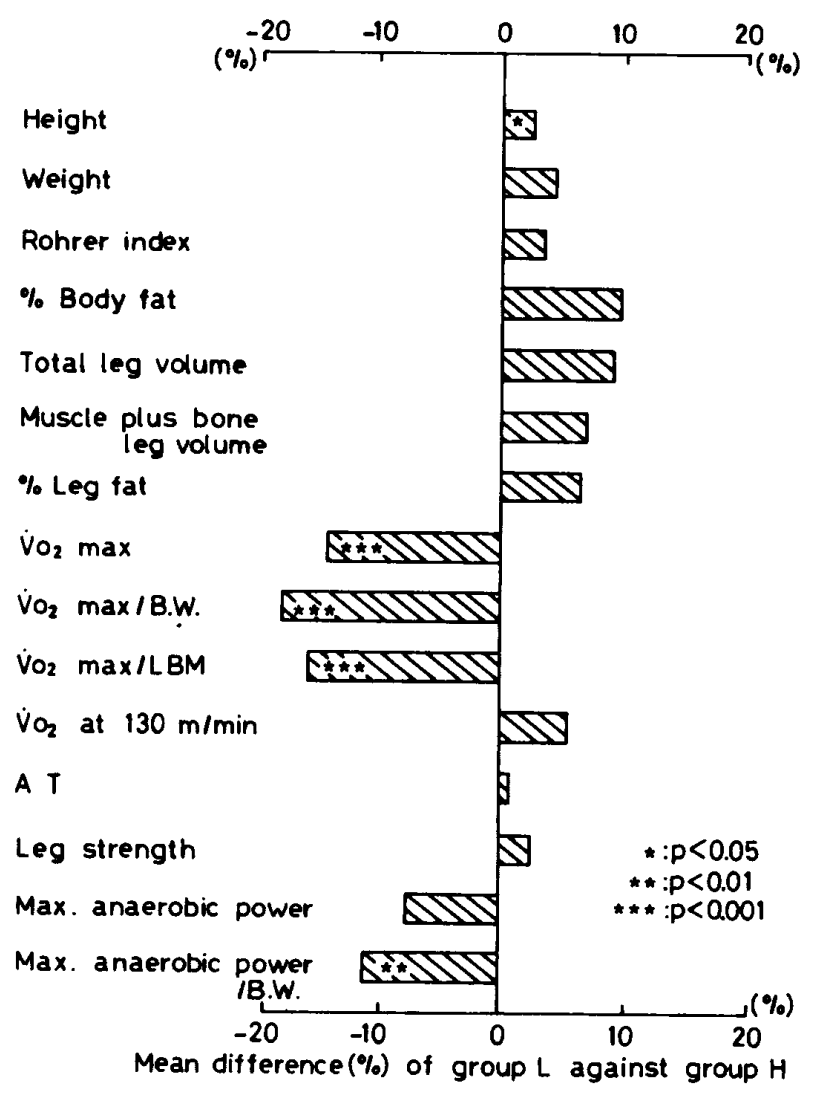

Group L: Subgroup selected trom low endurance group (LEG). Group H: Subgroup selected from high endurance group (HEG).

Fig. 2 Comparison of each variable between group $\mathrm{L}$ and group $\mathrm{H}$ as expressed by mean difference.

体組成に関する項目は, 低位者群のほ5が 4.6一10\%大きな値を示していたが, 有意差は認め られなかった。最大酸素㩒取量は低位者群のは5 
Table 2 Mean, SD and mean difference of each variable in group L and group $\mathrm{H}$.

\begin{tabular}{|c|c|c|c|}
\hline \multirow{2}{*}{ Variable } & Group L $†$ & Group H Ht & \multirow{2}{*}{$\begin{array}{c}\text { Mean } \\
\text { difference }\end{array}$} \\
\hline & Mean $\pm S D$ & Mean \pm SD & \\
\hline $\mathrm{N}$ of subjects & 9 & 14 & \\
\hline Height $(\mathrm{cm})$ & $158.3 \pm 3.3$ & $154.3 \pm 4.4$ & $4.0^{*}$ \\
\hline Weight $(\mathrm{kg})$ & $50.2 \pm 3.7$ & $48.0 \pm 4.5$ & 2.2 \\
\hline 12-min run performance $(m)$ & $1876.6 \pm 88.3$ & $2527.8 \pm 74.4$ & $-651.2^{* * *}$ \\
\hline$\%$ Body fat $(\%)$ & $23.0 \pm 4.0$ & $20.9 \pm 5.1$ & 2.1 \\
\hline Rohrer index & $126.1 \pm 9.2$ & $130.9 \pm 13.5$ & -4.5 \\
\hline Total leg volume $(l)$ & $7.10 \pm 0.69$ & $6.51 \pm 1.15$ & 0.59 \\
\hline Muscle plus bone leg volume( $l$ ) & $4.97 \pm 0.48$ & $4.66 \pm 0.66$ & 0.32 \\
\hline$\%$ Leg fat $(\%)$ & $29.8 \pm 3.4$ & $28.0 \pm 3.6$ & 1.8 \\
\hline $\mathrm{VO}_{2} \max (l / \min )$ & $1.929 \pm 0.164$ & $2.254 \pm 0.183$ & $-0.325^{* * *}$ \\
\hline $\mathrm{Vo}_{2} \max (\mathrm{ml} / \mathrm{kg} \cdot \min )$ & $38.5 \pm 2.2$ & $47.1 \pm 3.1$ & $-8.6^{* * *}$ \\
\hline $\mathrm{Vo}_{2} \max (\mathrm{ml} / \mathrm{LBM} \cdot \min )$ & $50.1 \pm 3.6$ & $59.6 \pm 3.3$ & $-9.5^{* * *}$ \\
\hline $\mathrm{HR} \max ($ beats $/ \min )$ & $187.3 \pm 12.9$ & $187.4 \pm 13.2$ & -0.1 \\
\hline $\mathrm{V}_{2}$ at $130 \mathrm{~m} / \mathrm{min}(\mathrm{ml} / \mathrm{kg} \cdot \mathrm{min})$ & $33.2 \pm 2.1$ & $31.5 \pm 3.1$ & 1.7 \\
\hline Anaerobic threshold $\left(\% \mathrm{Vo}_{2} \max \right)$ & $62.6 \pm 11.4$ & $62.3 \pm 10.2$ & 0.3 \\
\hline Leg strength(ft. lbs.) & $92.3 \pm 22.9$ & $90.1 \pm 19.4$ & 2.2 \\
\hline Max. anaerobic power $(\mathrm{kg} \cdot \mathrm{m} / \mathrm{sec})$ & $39.1 \pm 5.6$ & $42.5 \pm 5.5$ & -3.4 \\
\hline Max. anaerobic power/body weight & $0.78 \pm 0.10$ & $0.88 \pm 0.07$ & $-0.10^{* *}$ \\
\hline
\end{tabular}

$*: p<0.05, * * p<0.01, * *: p<0.001$

$\dagger$ : Subgroup which was selected from low endurance group(LEG).

† : Subgroup which was selected from high endurance group(HEG).

が有意に劣り，その差は絶対值で $0.325 \mathrm{l} / \mathrm{min}$ $(14.4 \%)$, 体重当りで $8.6 \mathrm{ml} / \mathrm{kg} \cdot \min (18.2 \%)$, $\mathrm{LBM}$ 当りで $9.5 \mathrm{ml} / \mathrm{kg} \cdot \mathrm{min}(15.9 \%)$ であった。 走効率は低位者群が $1.7 \mathrm{ml}(5.3 \%)$ 大きな值で あった。最高心拍数・AT および最大脚伸展筋力は ほぼ同様な值であった，最大無酸素パワーは低位 者群のほ 5 か $3.4 \mathrm{~kg} \cdot \mathrm{m} / \mathrm{sec}(8.0 \%)$ 低い值を示 し，体重当りで比較すると $0.10 \mathrm{~kg} \cdot \mathrm{m} / \mathrm{sec}$ （11.4\%）で $1 \%$ 水準で有意に劣っていた。

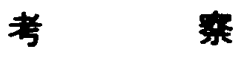

トレッドミル速度漸増テスト時の各被験者の $\mathrm{RPE}$ と走行スピードの相関係数は, 平均值が $0.963 \pm 0.040 て ゙ あ り$, 全員直線関係にあり，12分 間走平均スピード時のRPEは，低位者群が $15.2 \pm 0.8$, 高位者群が $15.2 \pm 2.1$ と平均値は等し かった。この值は小野寺と宮下 ${ }^{20)}$ 日本語スケ一 ルの「きつい」に相当し，両群とも12分間走テス トではよく努力していたものと思われる，両群の 12分間走距離を体育科学センター ${ }^{25)}$ による 5 段階 評価表と比較すると，それぞれ「やや低い」と「や
や高い」に相当する. Sparling と Cureton'24は, 規則的なランニング・トレーニングを行った平均

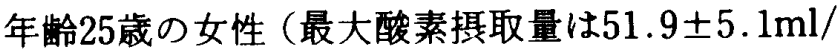
$\mathrm{kg} \cdot \mathrm{min}$ )の12分間走距離とし $2,747 \pm 186 \mathrm{~m}$ を ま た神山ら (4)は，定期的なスポーツ活動を行ってい る女子学生（最大酸素摄取量は $50.4 \pm 7.8 \mathrm{ml} / \mathrm{kg}$ ・

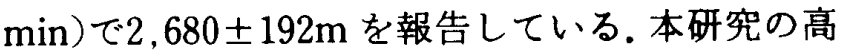
位者群の値は体育科学センターの「やや高い」以 上に属するものの，規則的な身体活動を行った Sparling とCureton ${ }^{24)}$ や神山ら ${ }^{14)}$ の值よりは劣 ク，一般女子学生の中の持久力に優れた群と思わ れる。一方, 低位者群の值は神山ら ${ }^{14}$ の報告による 一般女子学生の $2,223 \pm 160.3 \mathrm{~m}$ 上り䄪 $350 \mathrm{~m}$ 劣 り，かなり持久力の贫る群と見られる。

12分間走は個人の体重が負荷となるため, 体脂 肪率の多少が記録に大きく影響する。北川161は 18一-24歳の一般女性の体脂肪率として，22.3土 $4.4 \%$ 報告しており，また豊岡と高橋27は日本の 一線級女子中長距離選手の平均値として $14 \%$ を報 告している，本研究の低位者群と高位者群の平均 値は，それぞれ23.0，20.9\%で，豊岡と高橋27の報 
告よりは多いるのの，高位者群では北川 ${ }^{16)}$ の報告 より $2.0 \%$ 少ない体脂肪率である.しかし，両群の 差は $2.1 \%$ とそれはど多くなく，このことはTable 1に見られるよ5に，全女子新入生の体脂肪率の平 均値が $21.5 \pm 3.4 \%$ と全体として肥満傾向の者が 少なく，その上，両群の被験者を選んた12分間走 距離の最も劣るグループと優れたグループ間の差 る少なかったことによると思われる。

Davies と Sargeant ${ }^{71}$ は, 脚あるいは腕の容量と 最大酸素撮取量との間に正の相関関係を報告して いる.しかし本研究においては，走運動の主活動 筋である脚の筋・骨容量は，有意ではないものの 低位者群のほ5が0.32l（6.9\%）大きな值であり， 最大酸素撕取量の差を脚の筋・骨容量からは説明 できなかった，最大酸素摄取量を LBM 当りで比 較すると，低位者群のほうが9.5ml (15.9\%) 小さ な值である，低位者群の LBM 当りの最大酸素摂 取量は，同年龄の一般女子による北川ら ${ }^{17)}$ の 50.0 $\mathrm{ml}$ や, MacNab ら ${ }^{18)}$ の $50.4 \mathrm{ml}$ とほぼ同値であっ たが，高位者群の值は一般男子による北川ら $59.7 \mathrm{ml}$ や $\mathrm{MacNab}$ ら $^{18)}$ の59.4ml という報告に 匹敵していた。このように，両群の脚の筋・骨容 量はそれほど変らないにすかかわらず，LBM 当 りの最大酸素摄取量が劣るといらことは，活動筋 の酸化能力および酸素運搬を行う呼吸循環機能 が，低位者群は高位者群より劣ることを意味する あのと考えられる。

スピード $130 \mathrm{~m} / \mathrm{min}$ 時の酸素摄取量は，低位者 群のほ 向が見られた. Bransford と Howley ${ }^{31}$ は，女性の untrained $と$ trained $の$ running economy $の$ 比較 において，本研究と同様な報告をしている，本研 究の高位者群について, 走行スピード170,180m/ min 時の酸素摄取量を計算し，トレーニングを積 んだ女子被験者による Conley ら ${ }^{4}$ や Sparling と Cureton ${ }^{24)}$ の報告と比較すると, 本研究の高位者 群のほうが3- $5 \mathrm{ml}$ 多く, 走効率が劣っていた。規 則的なランニング・トレーンングは最大酸素撕取 年や走効率を改善するとされている21,4. 本研究の 両群はいずれも規則的なランニング・トレーニン グを行っていないので，最大酸素摄取量と同様，
走奻率る諸報告より劣っていたものと思われる。

最大脚伸展筋力は両群ほぼ同様な値であった が，最大無酸素パワーは高位者群のはらが大きな 値を示し，体重当りで比較すると $1 \%$ 水準で高位 者群のほうが有意に優れていた（Table 2, Fig. 2). 最大無酸素パワーの差の要因は, 力一速度関 係式より理論的な最大筋力と最大速度を求めた結 果, 低位者群の値はそれぞれ $37.5 \pm 3.2 \mathrm{~kg}, 2.6 \pm$ $0.4 \mathrm{~m} / \mathrm{sec}$ で, 高位者群は37.5 $55.0 \mathrm{~kg}, 3.2 \pm 0.3$ $\mathrm{m} / \mathrm{sec}$ であり, 最大筋力の平均值は同值であった が，最大速度は低位者群のほ (18.7\%, 有意)も劣っており，また，最大無酸素 パワー出現時の力・速度においても，低位者群と 高位者群の力の平均値はそれぞれ $21.6 \pm 2.0$, $21.1 \pm 2.4 \mathrm{~kg}$ でほぼ同値であったが，速度はそれ ぞれ $1.80 \pm 0.12,2.02 \pm 0.18 \mathrm{~m} / \mathrm{sec}$ で，低位者群 が $0.22 \mathrm{~m} / \mathrm{sec}(10.9 \%) 1 \%$ 水準で有意に遅く，こ のことが最大無酸素パワーの差に大きく影響して いた. 12分間走距離と最大無酸素パワーの相関係 数は, $\mathrm{r}=0.474$ と正の相関関係にあった. Table 1 に示すよ5に，12分間走距離と垂直とびについて も同様に正の相関が見られている。女性による結 果ではないが, Kaczkowski ら ${ }^{13)} は$ はレーニング を積んだ男子学生を被験者として，12分間走距離 と最大無酸素パワーの間に $\mathrm{r}=-0.62$ と負の相関 関係を報告している。 また, Katch と Waltman ${ }^{15)}$ $\ngtr$ Crielaard $\measuredangle$ Cureton $^{6}$ t aerobic power $と$ anaerobic powerの間に負の相関を報告してお り, 本研究の結果はこれらの報告と逆の相関関係 を示している。このことは Crielaard と Cureton ${ }^{6)}$ も指摘しているよ5に，一般学生では有酸素的あ るいは無酸素的能力を左右する筋の組織学的・生 化学的特徵がいずれか一方に偏っていないためな のか, あるいは両群ともその特徽が十分トレー二 ングされていないために，個人の能力特性が示さ れていなかったことによると考えられる。

Sparling とCureton ${ }^{24)}$ は12分間走距離を従属 変数とし，最大酸素摄取量・体脂肪率・running economy を独立変数とする重回㷌分析を行い, 12 分間走距離には最大酸素摄取量・体脂肪率・running economy の順で貢献しており, その寄与率 
Table 3. Summary results of multiple-regression analysis(stepwise method) predicting the 12 -min run performance.

\begin{tabular}{|c|c|c|c|c|c|c|c|c|}
\hline & & \multicolumn{7}{|c|}{ Analysis of variance } \\
\hline & & & & DF & \multicolumn{2}{|c|}{ Sum of squares } & \multicolumn{2}{|c|}{ Mean square } \\
\hline Multiple R & 0.967 & \multicolumn{2}{|c|}{ Regression } & 3 & \multicolumn{2}{|c|}{2299963.604} & \multicolumn{2}{|c|}{766654.535} \\
\hline $\mathrm{R}$ square & 0.936 & \multicolumn{2}{|c|}{ Residual } & 19 & \multicolumn{2}{|c|}{157523.353} & \multicolumn{2}{|c|}{8290.703} \\
\hline \multirow[t]{2}{*}{ Standard erro } & 91.053 & \multicolumn{7}{|c|}{$\mathrm{F}$ value $=92.472$} \\
\hline & & & \multicolumn{6}{|c|}{ Multiple regression equation } \\
\hline \multicolumn{3}{|c|}{ Independent variable } & \multicolumn{3}{|c|}{ Regression coefficient } & SE B Ht & BETA t+t & $T$ value \\
\hline \multicolumn{3}{|c|}{$\dot{\mathrm{VO}}_{2}$ max per body weight } & \multicolumn{3}{|c|}{55.0089} & 4.1599 & 0.8364 & 13.224 \\
\hline \multicolumn{3}{|c|}{ Running economy } & \multicolumn{3}{|c|}{-51.9292} & 6.9282 & -0.4394 & -7.495 \\
\hline \multirow{2}{*}{\multicolumn{3}{|c|}{$\begin{array}{l}\text { Max. anaerobic power } \\
\text { per body weight } \\
\text { (CONSTANT) }\end{array}$}} & \multicolumn{3}{|c|}{437.4195} & 218.8986 & \multirow[t]{2}{*}{0.1263} & 1.998 \\
\hline & & & & .8922 & & 321.5437 & & 4.279 \\
\hline
\end{tabular}

\footnotetext{
$\dagger$ : Multiple correlation coefficient

t† : Standard error of regression coefficient

ttt : Standardized regression coefficient
}

は62.4\%であると報告している. Table 3は本研 究について，12分間走距離を従属変数とするス テップワイズ方式による重回㷌分析を行い，3つ までの独立変数を投入した場合の結果を示したも のである、投入された独立変数は最大酸素摄取 量・走効率・体重当りの最大無酸素パワーであり， その重相関係数は $\mathrm{r}=0.967$ で寄与率は $93.6 \%$, 標 準誤差は $91.0 \mathrm{~m}$ であった。これらの独立変数の 12 分間走距離に対する貢献度は, 標準化回帰係数に 見られるよ5に，最大酸素摄取量・走効率・体重 当り最大無酸素パワーの順であり, 最大酸素摄取 量でもって約70\%を説明することが可能である。 体脂肪率が Sparling とCureton ${ }^{24)}$ の報告のよ5 に貢献度を示さなかったのは，本研究の被験者の 体脂肪率が，12分間走距離の差の割には大きな差 がなかった集団であることと，最大酸素摄取量と の内部相関によるものと思われる。

以上，12分間走距離から見た，一般女子学生の 持久力の低位者之高位者の体組成・有酸素的拉よ び無酸素的能力を比較すると，低位者は体脂肪 率・最大酸素摄取量・走奻率なと，ATを除く有酸 素的能力だけでなく，最大無酸素パワーにも劣る ことが認められた。 また，12分間走距離に最も影 響するのは最大酸素摄取量であり，続いて走効 率・最大無酸素パーの順であり，持久力低位者
の指導に際しては，これらの要因に対する考虑も 必要であろう。

\section{ま と め}

女子学生を対象として，持久力低位者の体力特 徵と 12 分間走距離への各能力の貢献度を検討する ため，12分間走テストの劣る者（1959m 以下） 9 名と優れた者 $(2,457 \mathrm{~m}$ 以上) 14 名と被験者とし, 両群の体組成・有酸素的能力・走効率 - 最大無酸 素パワー・最大脚伸展筋力を測定した結果, 次の ことが認められた。

1. 大学女子新入生（437名）の12分間走テスト と体脂肪率の平均值と標準偏差は，それぞれ

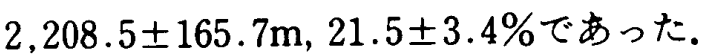

2. 12 分間走低位者群は高位者群より最大酸素 摄取量は $16.8 \%$ （有意）低く，また，同一最大下 作業時の酸素摄取量は $5.4 \%$, 体脂肪率は $10.0 \%$ 大 きな値であった，高位者群の最大酸素摄取量は一 般男子の値に匹敵していた。

3. 最高心拍数・AT・最大脚伸展筋力は両群ほ

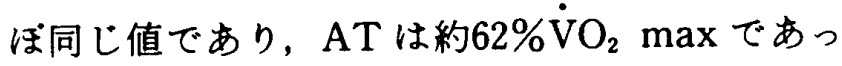
た.

4.最大無酸素パワーは低位者群のほ5が $11.4 \%$ (有意) 小さく，これは低位者群のほらが 力一速度関係において，最大速度と最大無酸素ハ 
ワー出現時の速度が劣っていることが原因であっ た.

5. 重回㷌分析（ステップワイズ方式）の結果, 12分間走距離には最大酸素摂取量・走効率・最大 無酸素パワ一の独立変数の順で貢献しており, そ の重相関係数は0.967で笴与率は93.6\%であった。

\section{引用・参考文献}

1) Astrand, P.-O. and Rodahl, K., Textbook of work physiology, McGraw-Hill : New York, 1970. pp. 303 -05 .

2) Bergh, U., Thorstensson, A., Sjödin, B., Hulten, B., Piehl, K. and Karlsson, J., "Maximal oxygen uptake and muscle fiber types in trained and untrained humans," Med. Sci. Sports, $10: 151-54,1978$.

3) Bransford, D.R. and Howley, E.T., "Oxygen cost of running in trained and untrained men and women," Med. Sci. Sports, $9: 41-44,1977$.

4) Conley, D.L., Krahenbuhl, G.S., Burkett, L.B. and Millar, A.L., "Physiological correlates of female road racing performance," Res. Quart. for Exercise and Sport, 52: 441-48, 1981.

5) Costill, D.L., Thomason, H. and Roberts, E., "Fractional utilization of the aerobic capacity during distance running," Med. Sci. Sports, 5 : 248-52, 1973.

6) Crielaard, J.M. and Cureton, F., "Anaerobic and aerobic power of top athletes,". J. Appl. Physiol., 47 : 295-300, 1981.

7) Davies, C.T.M. and Sargeant, A.J., "Physiological responses to standardized arm work," Ergonomics, 17: 41-49, 1974.

8) Davis, J.A., Frank, M.H., Whipp, B.J. and Wasserman, K., "Anaerobic threshold alterations caused by endurance training in middle-aged men," J. Appl. Physiol.: Respirat. Environ. Exercise Physiol., 46: 1039-46, 1979.

9) Davis, J.A., Vodak, P., Wilmore, J.H., Vodak, J. and Kurtz, P., "Anaerobic threshold and maximal aerobic power for three modes of exercise," J. Appl. Physiol., $41: 544-50,1976$.

10) Farrell, P.A., Wilmore, J.H., Coyle, E.F., Billing, J. E. and Costill, D.L., "Plasma lactate accumulation and distance running performance," Med. Sci. Sports, $11: 338-44,1979$.

11）生田香明・中塘二三生・根本哲朗・播本定彦「スプリ ンターのパワー発現」体力科学，29：143-51，1980.

12) Jones, P.R.M. and Pearson, J., "Anthropometric determination of leg fat and muscle plus bone volumes in young male and female adults," J. Physiol.
(Lond.), $204: 63-66,1969$.

13) Kaczkowski, W., Montgomery, D.L., Taylor, A.W. and Klissouras, V., "The relationship between muscle fiber composition and maximal anaerobic power and capacity." J. Sports Med., 22 : 407-13, 1982.

14）神山雄一郎・山西哲郎・桜井隆志・斉藤三郎「女子大 生における十二分走テストと最大酸素掑取量について」 日本体育学会群馬支部 - 体育学研究, 6:11-18, 1983.

15) Katch, V.L. and Weltman, A., "Interrelationship between anaerobic power output, anaerobic capacity and aerobic power," Ergonomics, $22: 325-32,1979$.

16）北川 㟟「日本人青年男女の身体組成とその国際比較」 保健の科学, $20: 491-95,1978$.

17）北川覃・宮下充正・山本恵三「青年男女の身体組成, 最大酸素摄取量および2400m走」体育学研究，21： 335-40, 1977.

18) MacNab, R.B.J., Conger, P.R. and Taylor, P.S., "Differences in maximal and submaximal work capacity in men and women," J. Appl. Physiol., 27 : 644-48, 1969.

19）長嶺晋吉,「肥満と体重减量法」長嶺晋吉(編), スポー ッとエネルギー・栄養, 現代のスポーッ科学第 2 巻, 大 館書店, 1979, pp. 259-83.

20）小野寺孝一・宮下充正「全身持久性運動に拈ける主観 的運動强度と客锤的強度の対応性一Rating of preceived exertionの観点から一」体育学研究, 21 : 191-203, 1976.

21) Powers, S.K., Dodd, S., Deason, R., Byrd, R. and Mcknight, T., "Ventilatory threshold, running ecnomy and distance running performance of trained athletes," Res. Quart. for Exercise and Sport, $54: 179$ $-82,1983$.

22) Ready, A.E. and Quinney, H.A., "Alterations in anaerobic threshold as the result of endurance training and detraining," Med. Sci. Sports Exerc., $14: 292$ $-96,1982$.

23) Rusko, H., Rahkola, P. and Karvinen, E., "Anaerobic threshold, skeletal muscle enzymes and fiber composition in young female cross-country skiers," Acta Physiol. Scand., 108 : 263-68, 1980.

24) Sparling, P.B. and Cureton, K.J., "Biological determinants of the sex difference in 12-min run performance," Med. Sci. Sports Exerc., $15: 218-23,1983$.

25）体育科学センター(編), 健康づくり運動カルテ, 譜談 社, 1980, pp. 33-48.

26）東京都立大学身体道性学研究室編，日本人の体力標準 値，第二版，不眛堂出版，1975。 pp. 446.

27）豊岡示朗・高橋第志「女子中距離選手の身体的並びに 生理学的プロフィール」大阪体育大学紀要, $13: 45-53$, 1982. 